\title{
Bioactive Compounds from Mangosteen (Garcinia mangostana L.) as an Antiviral Agent via Dual Inhibitor Mechanism against SARS- CoV-2: An In Silico Approach
}

\author{
ANM Ansori' ${ }^{1}$, VD Kharisma ${ }^{2}$, AA Parikesit ${ }^{3}$, FA Dian ${ }^{4}$, RT Probojati ${ }^{5}$, M Rebezov $^{6,7}$, P Scherbakov ${ }^{8}$, P Burkov ${ }^{9}$, G \\ Zhdanova $^{7}$, A Mikhalev ${ }^{7}$, Y Antonius ${ }^{10}$, MRF Pratama ${ }^{11,12}$, NI Sumantri ${ }^{13}$, TH Sucipto ${ }^{14}$, R Zainul ${ }^{15, *}$
}

'Doctoral Program of Veterinary Science, Faculty of Veterinary Medicine, Universitas Airlangga, Surabaya, INDONESIA.

${ }^{2}$ Master Program of Biology, Department of

Biology, Faculty of Mathematics and Natural Sciences, Brawijaya University, Malang, INDONESIA.

${ }^{3}$ Department of Bioinformatics, School of Life Sciences, Indonesia International Institute for Life Sciences, Jakarta, INDONESIA. ${ }^{4}$ Department of Biochemistry and Biotechnology, Faculty of Agronomy, Horticulture and Bioengineering, Poznan University of Life Sciences, Poznan, POLAND. ${ }^{5}$ Faculty of Agriculture, Universitas Kadiri, Kediri, INDONESIA

${ }^{6}$ Faculty of Biotechnology and Food Engineering, Ural State Agrarian University, Yekaterinburg, RUSSIAN FEDERATION. ${ }^{7}$ K. G. Razumovsky Moscow State University of Technologies and Management (The First Cossack University), Moscow, RUSSIAN FEDERATION. ${ }^{8}$ Department of Infectious Diseases and Veterinary, South Ural State Agrarian University, Troitsk, RUSSIAN FEDERATION. ${ }^{9}$ Center for Biotechnology of Animal Reproduction, South Ural State Agrarian University, Troitsk, RUSSIAN FEDERATION. ${ }^{10}$ Faculty of Biotechnology, University of Surabaya, Surabaya, INDONESIA.

"Doctoral Program of Pharmaceutical Sciences, Faculty of Pharmacy, Universitas Airlangga, Surabaya, INDONESIA. ${ }^{12}$ Department of Pharmacy, Faculty of Health Sciences, Universitas Muhammadiyah Palangkaraya, Palangka Raya, INDONESIA.

${ }^{13}$ Biomedical Engineering Study Program, Department of Electrical Engineering, Faculty of Engineering, Universitas Indonesia, Depok, INDONESIA.

${ }^{14}$ Dengue Study Group, Institute of Tropical Disease, Universitas Airlangga, Surabaya, INDONESIA.

${ }^{15}$ Department of Chemistry, Faculty of Mathematics and Natural Sciences, Universitas Negeri Padang, Padang, INDONESIA.

Correspondence

\section{R Zainul}

Department of Chemistry, Faculty of

Mathematics and Natural Sciences, Universitas Negeri Padang, Padang, INDONESIA.

E-mail: rahadianzmsiphd@fmipa.unp.ac.id

History

- Submission Date: 19-11-2021

- Review completed: 20-12-2021;

- Accepted Date: 03-01-2022.

DOI : 10.5530/pj.2022.14.12

Article Available online

http://www.phcogj.com/v14/i1

Copyright

(C) 2022 Phcogj.Com. This is an openaccess article distributed under the terms of the Creative Commons Attribution 4.0 International license.

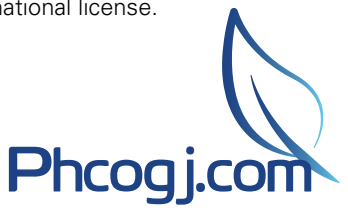

\begin{abstract}
Severe acute respiratory syndrome coronavirus 2 (SARS-CoV-2) is the virus that causes COVID-19 which is responsible for respiratory illness infection in humans. The virus was first identified in China in 2019 and later spread to other countries worldwide. This study aims to identify the bioactive compounds from mangosteen (Garcinia mangostana L.) as an antiviral agent via dual inhibitor mechanisms against two SARS-CoV-2 proteases through the in silico approach. The three-dimensional structure of various bioactive compounds of mangosteen from the database was examined. Furthermore, all the target compounds were analyzed for drug, antiviral activity prediction, virtual screening, molecular interactions, and threedimensional structure visualization. It aimed to determine the potential of the bioactive compounds from mangosteen that can serve as antiviral agents to fight SARS-CoV-2. Results showed that the bioactive compounds from mangosteen have the prospective to provide antiviral agents that contradict the virus via dual inhibitory mechanisms. In summary, the binding of the various bioactive compounds from mangosteen results in low binding energy and is expected to have the ability to induce any activity of the target protein binding reaction. Therefore, it allows various bioactive compounds from mangosteen to act as dual inhibitory mechanisms for COVID-19 infection.
\end{abstract}

Key words: Antiviral agent, COVID-19, Garcinia mangostana L., In silico approach, SARS-CoV-2.

\section{INTRODUCTION}

Coronavirus disease-2019 or COVID-19 pandemic which is caused by severe acute respiratory syndrome coronavirus 2 (SARS-CoV-2) had lead many disadvantages in the economy and health sector. ${ }^{1}$ The newest data reveal until October 2021 has been stated that approximately 245 million people and 5 million death has occurred across the world. Furthermore, more than 4.2 million people have been infected, with a total death of more than 140 thousand people happening in Indonesia. ${ }^{2}$

COVID-19 pandemic is the third noteworthy coronavirus outbreak in the twenty-first century, following the SARS and the Middle East respiratory syndrome (MERS) epidemics in 2002/2003 and $2012 .{ }^{3,4}$ In contrast to the extremely contagious and pathogenic SARS-CoV, MERS-CoV, and SARS-CoV-2, four more coronaviruses can infect human, including HCoV-229E, HCoV-HKU1, HCoV-NL63, and HCoV-OC43, which caused only mild respiratory sickness like the common cold. ${ }^{5}$ Additionally, rapid vaccination processes are still endlessly occurring by $\mathrm{WHO}$ and other various countries, including Indonesia. ${ }^{6,7}$ Yet, the discovery of an effective medicine in order to fight against SARS-CoV-2 is still barely reaching a satisfactory result. $^{8}$

SARS-CoV-2 is a virus that has $29,903 \mathrm{bp}$ genome in length (NCBI Reference Sequence: NC_045512.2) and has ssRNA as their genetic material. ${ }^{9}$ It has four structural proteins, which are envelope protein (E), membrane glycoprotein $(\mathrm{M})$, nucleocapsid phosphoprotein $(\mathrm{N})$, and spike glycoprotein (S). ${ }^{10}$ Furthermore, a number of nonstructural proteins has been mapped. ${ }^{11}$ In addition, two SARS-CoV-2 proteases: main protease $\left(\mathrm{M}^{\text {pro }}\right)$ and papain-like protease ( $\left.\mathrm{PL}^{\mathrm{pro}}\right)$, have an essential function in the discovery of antiviral therapy candidates. PL ${ }^{\text {pro }}$ had a role in the maturation and the cleavage of viral proteins, destroys of the host response, as well as in the replicase-transcriptase complex incorporation. Another protease, $\mathrm{M}^{\text {pro }}$ is used to induce the maturation and the cleavage of viral proteins throughout the process of virus replication. ${ }^{12,13}$

Indonesia is a nation enriched in biodiversity; there are roughly 40,000 plant species, of which around 7,500 are medicinal plants, whether native or introduced species, cultivated or wild. ${ }^{4}$ For ages, their worth has been recognized over the world for use as medications and cosmetics, as well as in traditional and modern applications. ${ }^{15}$ Garcinia mangostana $\mathrm{L}$. or mangosteen is a member of the Clusiaceae family and the genus Garcinia. ${ }^{16}$ Garcinia is a vast genus with 400 species native to East India, the Malay Peninsula, and Southeast Asia, including Indonesia. In truth, mangosteen is a tropical fruit that has been used as a traditional medicine for hundreds of years globally. ${ }^{17,18}$

Many researchers reported antiviral activity of mangosteen against chikungunya virus (CHIKV), porcine reproductive and respiratory syndrome virus (PRRSV), dengue virus (DENV), and avian pox
Cite this article: Ansori ANM, Kharisma VD, Parikesit AA, Dian FA, Probojati RT, Rebezov M, et al. Bioactive Compounds from Mangosteen (Garcinia mangostana L.) as an Antiviral Agent via Dual Inhibitor Mechanism against SARS-CoV-2: An In Silico Approach. Pharmacogn J. 2022;14(1): 85-90. 
virus. ${ }^{19-22}$ However, the potency of mangosteen against SARS-CoV-2 is remains unclear. Therefore, this study aimed to identify the potency of bioactive compounds derived from mangosteen as an antiviral agent via dual inhibitor mechanisms towards two SARS-CoV-2 proteases with in silico approach.

\section{MATERIALS AND METHODS}

\section{Sample retrieval}

The chemical compound of mangosteen which consisted of $\alpha$-mangostin (CID: 5281650), $\beta$-mangostin (CID: 5495925), and $\gamma$-mangostin (CID: 5464078) were collected from the PubChem database (https://pubchem.ncbi.nlm.nih.gov/) (Figures 1A, 1B, and 1C). Meanwhile, the targeted protein on SARS-CoV-2 which consisted of two non-structural proteins including main protease ( $\mathrm{M}^{\text {pro; }}$ PDB ID: 7ALH) and papain-like protease (PL ${ }^{\text {pro }}$ PDB ID: 7CMD) were obtained from the PDB (https://www.rcsb.org/) (Figures 1D and 1E).

\section{Drug likeness analysis}

Bioactive compounds such as $\alpha$-mangostin, $\beta$-mangostin, and $\gamma$-mangostin were used for further drug-likeness analysis using Lipinski's rule of five in SCFBIO web server (http://www.scfbio-iitd. res.in/software/drugdesign/lipinski.jsp). It considered as a positive prediction with two minimum rules which followed. This analysis aimed to determine the probability of the medicine molecule candidate to get through the cell membrane if the target were in the cytoplasm environment and pharmacokinetic. ${ }^{23}$

\section{Antiviral probability prediction}

Probability prediction of biological activity as an antivirus agent on the bioactive compounds of $\alpha$-mangostin, $\beta$-mangostin, and $\gamma$-mangostin was performed by using the PASS web server (http://way2drug.com/ PassOnline/). The threshold prediction with probability activation $(\mathrm{Pa})$ score $>0.3$ was considered as potential antivirus. ${ }^{23,24}$

\section{Virtual screening}

In this study, we performed molecular docking methods to know the activity of dual inhibitors on $\alpha$-mangostin, $\beta$-mangostin, and $\gamma$-mangostin compounds when they bind to target proteins (SARSCoV-2 $\mathrm{M}^{\text {pro }}$ and PL ${ }^{\text {pro }}$ ). The molecular docking was performed by using PyRx 0.9.9 software (Scripps Research, USA) with an academic license. The compound with the most negative affinity score on both targeted proteins was considered to have the ability to trigger the biologic response on the proteins as dual inhibitor. The binding ability in the molecular docking showed by the binding affinity score $(\mathrm{kcal} / \mathrm{mol})$, which formed within complex protein molecules and ligand. ${ }^{23}$

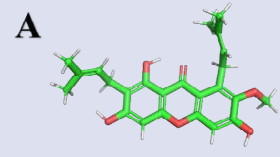

B

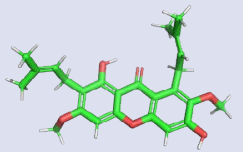

C

D

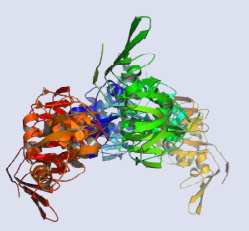

E

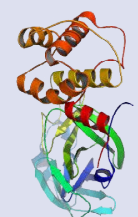

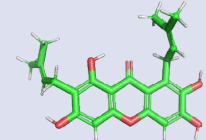

Figure 1: The chemical compound from mangosteen: A) a-Mangostin (CID: 5281650); B) $\beta$-Mangostin (CID: 5495925); C) $\gamma$-Mangostin (CID: 5464078); and targeted protein on the SARS-CoV-2: D) Main protease (Mro) (PDB ID: 7ALH); E) Papain-like protease (PL ${ }^{\text {pro }}$ ) (PDB ID: 7CMD).

\section{Chemical interaction and 3D molecular visualization}

Compound with the most negative binding affinity score was addressed for further analysis to find its position and chemical binding interaction type by using Discovery Studio Visualizer ${ }^{\mathrm{rat}}$ v.16.1 (Dassault Systèmes SE, France). The visualization process was performed by using PyMOL software v.2.5.2 (Schrödinger, Inc., USA) with an academic license. ${ }^{23,24}$

\section{RESULTS AND DISCUSSION}

Lipinski's rule of five is important in determining a medicine compound candidate as a drug-like molecule; those rules are consisted of molecule mass $<500$ Dalton, $\log \mathrm{P}<5$, the hydrogen binding donor $<5$, hydrogen binding donor $<10$, and molar refractivity between $40-130 .{ }^{25}$ According to the drug-likeness prediction, those three compounds, such as $\alpha$-mangostin, $\beta$-mangostin, and $\gamma$-mangostin, could comply all the Lipinski's rule of five. Therefore, it could be considered as drug-like molecule (Table 1).

The analyses result of the PASS web server, a compound with Pa score greater than Pi score, was predicted to have potential as antiviral. The Pa score $>0.3$ mean that the query compound has been more activated and it proved computationally. ${ }^{23}$ Antiviral analyses probability on this research was using threshold $\mathrm{Pa}>0.3$. Compounds with $\mathrm{Pa}$ score $>0.3$ are considered to have potency as antiviral agents. Results showed that all the compounds were considered as antivirus agents. However, their potential is stills need to be examined through further analysis by using in vitro or in vivo (Table 1).

The molecular docking for $\mathrm{M}^{\text {pro }}$ was conducted by using grid position with center $(\AA)$ X: -26.28 Y: 12.59 Z: 57.04 ; dimensions $(\AA)$ X: $51.37 \mathrm{Y}$ 66.97 Z: 63.44, while molecular docking for $\mathrm{PL}^{\text {pro }}$ was using grid position with center ( $)$ X: 12.29 Y: 7.07 Z: 17.99; dimensions $(\AA)$ X: $60.13 \mathrm{Y}$ : 88.85 Z: 65.73 . Binding affinity is defined as stable binding energy formed between protein-ligand complex. The level of binding affinity score may influence by biological activity when it binds to the targeted protein domain. The biological activity calculated is the inhibition response to the targeted protein. ${ }^{26}$ This inhibition of the targeted protein activity may decrease viral load SARS-CoV-2 production. ${ }^{27}$ Regarding the molecular docking simulation, the $\gamma$-mangostin compound has the most negative binding energy on both targeted proteins, and it may have potential as antiviral via dual inhibitor (Table 2).

The activity of $\mathrm{M}^{\text {pro }}$ and $\mathrm{PL}^{\text {pro }}$ when SARS-CoV-2 has performed a replication on the host cell depends on the catalytic site, based on Cys145 and His41 ( $\left.\mathrm{M}^{\mathrm{pro}}\right)$ as well as Pro248, Thr301, and Asp286 (PL $\left.{ }^{\text {pro }}\right) .^{28}$ The position and chemical binding type showed that $\gamma$-mangostin may interact on the catalytic site of $\mathrm{M}^{\text {pro }}$ at position Cys 145 and His41 through Pi bonding and it also had interaction with $\mathrm{PL}^{\text {pro }}$ with amino acid residue Pro248 and Thr301 along with the hydrogen bond and $\mathrm{Pi}$ (Figure 2). Moreover, the non-covalent interaction was also formed within the protein-ligand complex and it is considered to be able to trigger a specific biological response, such as inhibition. The inhibitor could induce the response on the target protein when the interaction resulted by hydrogen bonding. Then, the molecule flexibility may also influence by the Pi binding. ${ }^{29}$

Plants, used to treat illnesses, are both valuable and useful. They are defined as potential plants with therapeutic benefits based on their secondary metabolites compounds which had health-related effects, regardless of whether their utilization has been shown clinically. These plants can be collected from the wild or grown in a lab for benefit as food or cosmetics agents. Various plant components, extracts, and sophisticated products had been used to cure sickness for a long time. In brief, around the world, there are more than 50,000 higher plant species are regarded to be used for medicinal purposes. ${ }^{30}$

Former studies have been described the potential of mangosteen as an antiviral agent. The $\alpha$-mangostin is a potential natural antiviral 


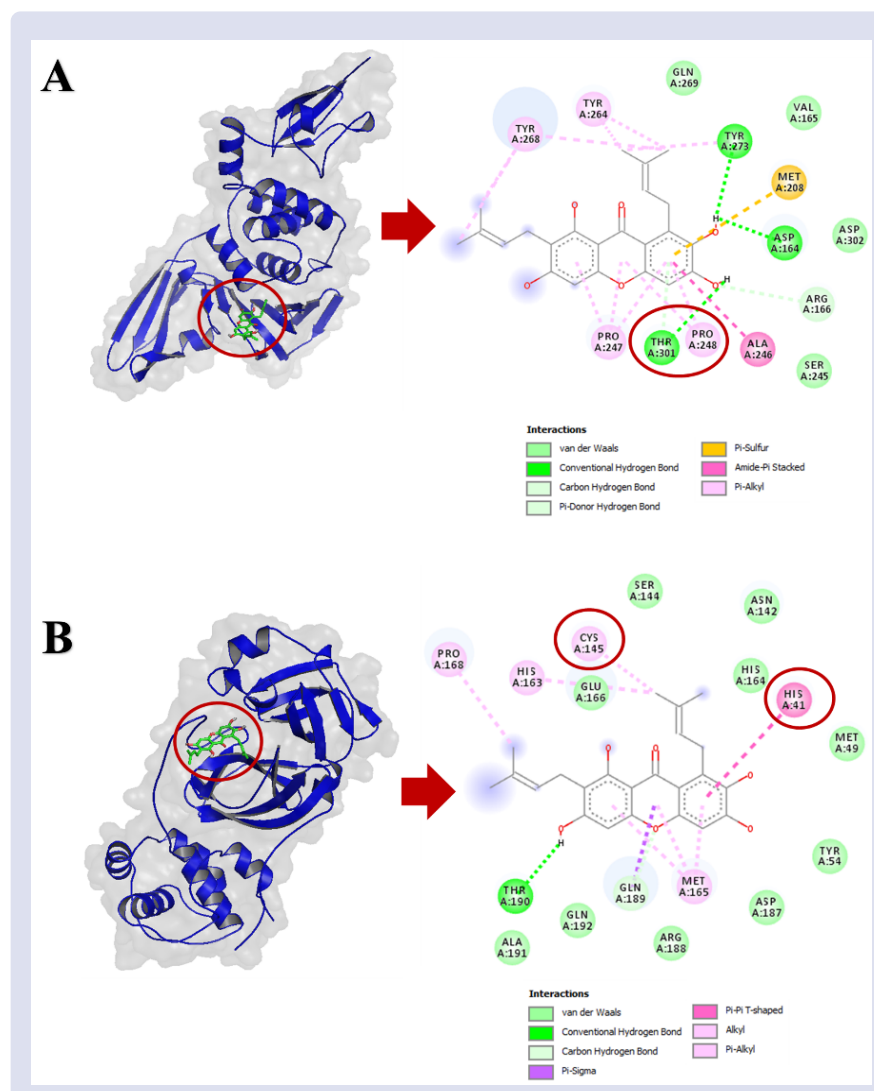

Figure 2: The binding visualization of $\gamma$-mangostin on the targeted protein: $A) M^{\text {pro }}$ and $\left.B\right) P^{\text {pro }}$.

Table 1: Analysis result of Lipinski's rule of five and prediction of antiviral activity.

\begin{tabular}{lcccccccc} 
Compounds & $\begin{array}{c}\text { MW } \\
(<500\end{array}$ & HBD & HBA & LogP & $\begin{array}{c}\text { MR } \\
(40-\end{array}$ & \multicolumn{2}{c}{$\begin{array}{c}\text { Antiviral } \\
\text { Probability }\end{array}$} \\
\cline { 8 - 10 } & & $<5$ & $<10$ & & & $130)$ & Pa & Pi \\
\hline a-mangostin & 410 & 3 & 6 & 5.16 & 114.20 & 0.423 & 0.026 \\
$\beta$-mangostin & 424 & 2 & 6 & 5.46 & 119.09 & 0.428 & 0.024 \\
$\gamma$-mangostin & 396 & 4 & 6 & 4.86 & 109.31 & 0.453 & 0.018
\end{tabular}

Note: Molecular weight (MW); Hydrogen bond donor (HBD); Hydrogen bond acceptor (HBA); High lipophilicity (LogP); and molar refractivity (MR).

Table 2: Binding affinity of complex compounds and protein.

\begin{tabular}{|cccc|}
\hline \multirow{2}{*}{ Compounds } & PubChem ID & \multicolumn{2}{c|}{ Binding Affinity (kcal/mol) } \\
\cline { 3 - 4 } & & M $^{\text {pro }}$ & PL $^{\text {pro }}$ \\
\hline a-mangostin & 5281650 & -7.5 & -7.3 \\
$\beta$-mangostin & 5495925 & -6.8 & -6.9 \\
$\gamma$-mangostin & 5464078 & -7.6 & -7.6 \\
\hline
\end{tabular}

agent to fight the chikungunya virus (CHIKV) through in vitro and in vivo experiments. ${ }^{19}$ Arjin et al. stated that Thai medicinal herbs, including mangosteen, were tested in vitro for antiviral efficacy against the porcine reproductive and respiratory syndrome virus (PRRSV). ${ }^{20}$ Previously, the ethanol extract of mangosteen was reported to inhibit HIV-1 protease with a high potency level..$^{21}$ Mangosteen ethanolic extract also inhibits avian poxvirus replication in vivo. ${ }^{22}$ Furthermore, another study, Panda et al. reported that in vitro and in silico data of $\alpha$-mangostin had the capacity to reduce DENV-2 production at various phases of its replication cycle. It is suggesting that it might be used as a DENV-2 prophylactic/therapeutic drug. ${ }^{23}$ Additionally, in DENVinfected immature monocyte-derived dendritic cells, $\alpha$-mangostin significantly inhibited cytokine/chemokine (IL1 $\beta$, TNF- $\alpha$, IL6, CCL4, IL10, CCL5, CXCL10, and IFN- $\alpha$ ) production. These findings point to the possibility of developing $\alpha$-mangostin as a new anti-DENV medication. ${ }^{31}$

Presently, the possibility of various medicinal plants for antivirus to fight against SARS-CoV-2 has been reported by many researchers globally. In Asia, the Chinese herbal medicine tested to encounter SARS-CoV-2 by several researchers using in silico, ${ }^{32,33}$ The traditional Himalayan medicinal plants also had been tested against SARS-CoV-2 which reported by Natesh et al..$^{34}$ Moreover, the Indian traditional medicine were also having a good antiviral potential towards the SARS-CoV-2 in silico analysis. ${ }^{35,36}$ Another research, including Brazilian, Peruvian, and Mexican herbal medicines from the American continent were also reported for having potential against SARS-CoV-2. ${ }^{37-39}$ Another point of view, numerous African medicinal plants were reported by researchers. ${ }^{40-43}$ Our former study revealed that an herbal combination of Moringa oleifera and Curcuma longa could be an antiviral agent via dual inhibitors pathway for SARS-CoV $-2 .{ }^{23}$

$\mathrm{M}^{\text {pro }}$ and $\mathrm{PL}^{\text {pro }}$ are two SARS-CoV-2 proteases that had an essential role as antiviral candidates. Both of the proteins contributed to the function of protein maturation, cleavage of viral proteins, binding complex of replicase-transcriptase, and the interfering for the host cells. Some of the studies explained that $\mathrm{M}^{\text {pro }}$ facilitated the discovery of the antiviral candidate obtained from medicinal plants. ${ }^{44-47}$ Moreover, PL ${ }^{\text {pro }}$ was also had been reported as the target to discover the antiviral candidate agents based on the herbal material. ${ }^{48-51}$ On another part, RdRp was also tested as an antiviral target candidate based on a herbal compound reported by Ahmad Mir et al. ${ }^{52}$ The result of the whole research may be used for support towards the development of the antiviral agent candidate. However, further analysis should be performed to confirm and uncover the further potential.

\section{CONCLUSION}

In summary, various bioactive compounds from mangosteen, such as $\alpha$-mangostin, $\beta$-mangostin, and $\gamma$-mangostin had low binding energy towards the targeted protein, $\mathrm{M}^{\mathrm{pro}}$ and $\mathrm{PL}^{\text {pro }}$. It is expected to have the ability to induce that protein activity. Furthermore, those bioactive compounds have demonstrated the ability to be developed as an antiviral drug which is depicted by Lipinski's rule of five and antiviral activity prediction. Therefore, the bioactive compounds from mangosteen are considered as dual inhibitory mechanisms for COVID-19 infection.

\section{ACKNOWLEDGEMENT}

This manuscript is dedicated to the memory of Dr. Saikhu Akhmad Husen, M.Kes. who sadly passed away on Saturday 17th July, 2021. May he rest in peace. Additionally, this study supported by the Ministry of Education, Culture, Research, and Technology of Republic of Indonesia for PTUPT (Grant Number: 414/UN35.13/LT/2021) and Rector of Universitas Negeri Padang, Indonesia (Grant Number: 1008/UN35.13/ LT/2021). We thank EJA Team, Indonesia (https://ejatranslation. wixsite.com/home) for editing the manuscript.

\section{DISCLOSURE STATEMENT}

The authors have declared that no competing interests exist.

\section{ABBREVIATIONS}

CHIKV: Chikungunya virus; COVID-19: Coronavirus disease-2019; DENV-2: Dengue virus serotype 2; HIV-1: Human immunodeficiency virus 1; $\mathrm{M}^{\text {pro }}$ : Main protease; MERS: Middle East respiratory syndrome; PL ${ }^{\text {pro }}$ : Papain-like protease; PDB: Protein Data Bank; PRRSV: Porcine reproductive and respiratory syndrome virus (PRRSV); SARS-CoV: Severe acute respiratory syndrome coronavirus; SARS-CoV-2: Severe acute respiratory syndrome coronavirus 2; WHO: World Health Organization. 
Ansori ANM, et al.: Bioactive Compounds from Mangosteen (Garcinia mangostana L.) as an Antiviral Agent via Dual Inhibitor Mechanism against SARS-CoV-2: An In Silico Approach

\section{REFERENCES}

1. Ansori ANM, Kharisma VD, Muttaqin SS, Antonius Y, Parikesit AA. Genetic variant of SARS-CoV-2 isolates in Indonesia: Spike glycoprotein gene. J Pure Appl Microbiol. 2020;14:971-978.

2. Dong $E$, Du H, Gardner L. An interactive web-based dashboard to track COVID-19 in real time. Lancet Infect Dis. 2020;20(5):533-534.

3. Lai CC, Shih TP, Ko WC, Tang HJ, Hsueh PR. Severe acute respiratory syndrome corona virus 2 (SARS-CoV-2) and corona virus disease-2019 (COVID-19): The epidemic and the challenges. Int J Antimicrob Agents. 2020;55:105924

4. Corona viridae Study Group of the International Committee on Taxonomy of Viruses. The species severe acute respiratory syndrome-related corona virus: Classifying 2019-nCoV and naming it SARS-CoV-2. Nat Microbiol. 2020;5(4):536-544

5. Liu DX, Liang JQ, Fung TS. Human coronavirus-229E, -OC43, -NL63, and -HKU1 (Corona viridae). Encyclopedia of Virology. 2021;428-440.

6. Kharisma VD, Ansori ANM. Construction of epitope-based peptide vaccine against SARS-CoV-2: Immunoinformatics study. J Pure Appl Microbiol. 2020;14:6248.

7. Ophinni Y, Hasibuan AS, Widhani A, Maria S, Koesnoe S, Yunihastuti $\mathrm{E}$, et al. COVID-19 vaccines: Current status and implication for use in Indonesia. Acta Med Indones. 2020;52(4):388-412.

8. Jain R, Mujwar S. Repurposing metocurine as main protease inhibitor to develop novel antiviral therapy for COVID-19. Struct Chem. 2020;1-13.

9. Laamarti M, Chemao-Elfihri MW, Kartti S, Laamarti R, Allam L, Ouadghiri $M$, et al. Genome sequences of six SARS-CoV-2 strains isolated in Morocco, obtained using Oxford Nanopore MinION technology. Microbiol Resour Announc. 2020;9(32):e00767-20.

10. Hafidzhah MA, Wijaya RM, Probojati RT, Kharisma VD, Ansori ANM, Parikesit AA. Potential vaccine targets for COVID-19 and phylogenetic analysis based on the nucleocapsid phosphoprotein of Indonesian SARS-CoV-2 isolates. Indonesian J Pharm. 2021;32(3):328-337.

11. Yadav R, Chaudhary JK, Jain N, Chaudhary PK, Khanra S, Dhamija P, et al. Role of structural and non-structural proteins and therapeutic targets of SARS-CoV-2 for COVID-19. Cells. 2021;10(4):821.

12. Nogara PA, Omage FB, Bolzan GR, Delgado CP, Aschner M, Orian $\mathrm{L}$, et al. In silico studies on the interaction between Mpro and PLpro from SARS-CoV-2 and ebselen, its metabolites and derivatives. Mol Inform. 2021;40(8):e2100028.

13. Sabbah DA, Hajjo R, Bardaweel SK, Zhong HA. An updated review on SARS-CoV-2 main proteinase (MPro): Protein structure and smallmolecule inhibitors. Curr Top Med Chem. 2021;21(6):442-460.

14. Ansori ANM, Kusala MKJ, Irawan $H$, Putri N, Fadholly A, Proboningrat A, Rukmana S, Karni I, Anisa AK, Adrianto H. Citrus reticulata extract as biocides to control Aedes aegypti, the vector of dengue. Biosci Res. 2018;15:1661-1665.

15. Rosmalena R, Elya B, Dewi BE, Fithriyah F, Desti H, Angelina M, et al. The antiviral effect of Indonesian medicinal plant extracts against dengue virus in vitro and in silico. Pathogens. 2019;8(2):85.

16. Ansori ANM, Fadholly A, Hayaza S, Susilo RJK, Inayatillah B, Winarni $D$, et al. A review on medicinal properties of mangosteen (Garcinia mangostana L.). Res J Pharm Tech. 2020;13(2):974-982.

17. Ovalle-Magallanes B, Eugenio-Pérez D, Pedraza-Chaverri J. Medicinal properties of mangosteen (Garcinia mangostana L.): A comprehensive update. Food Chem Toxicol. 2017;109(Pt 1):102-122.

18. John OD, Mouatt P, Panchal SK, Brown L. Rind from purple mangosteen (Garcinia mangostana) attenuates diet-induced physiological and metabolic changes in obese rats. Nutrients. $2021 ; 13(2): 319$.
19. Patil P, Agrawal M, Almelkar S, Jeengar MK, More A, Alagarasu K, et al. In vitro and in vivo studies reveal a-mangostin, a xanthonoid from Garcinia mangostana, as a promising natural antiviral compound against chikungunya virus. Virol J. 2021;18(1):47

20. Arjin C, Pringproa K, Hongsibsong S, Ruksiriwanich W, SeelAudom M, Mekchay $S$, et al. In vitro screening antiviral activity of Thai medicinal plants against porcine reproductive and respiratory syndrome virus. BMC Vet Res. 2020;16(1):102.

21. Nur'aini $A L$, Hartati $S$, Untari T. In ovo inhibition of avian pox virus replication by mangosteen rind and red ginger ethanolic extracts. Vet World. 2021;14(10):2640-2645.

22. Panda K, Alagarasu K, Patil P, Agrawal M, More A, Kumar NV, et al. In vitro antiviral activity of $\alpha$-mangostin against dengue virus serotype-2 (DENV-2). Molecules. 2021;26(10):3016.

23. Kharisma VD, Agatha A, Ansori ANM, Widyananda MH, Rizky WC, Dings TGA, et al. Herbal combination from Moringa oleifera Lam. and Curcuma longa L. as SARS-CoV-2 antiviral via dual inhibitor pathway: A viroinformatics approach. J Pharm Pharmacogn Res. 2022;10(1):138-146.

24. Widyananda MH, Pratama SK, Samoedra RS, Sari FN, Kharisma VD Ansori ANM, et al. Molecular docking study of sea urchin (Arbacia lixula) peptides as multi-target inhibitor for non-small cell lung cancer (NSCLC) associated proteins. J Pharm Pharmacogn Res. $2021 ; 9(4): 484-496$

25. Chagas CM, Moss S, Alisaraie L. Drug metabolites and their effects on the development of adverse reactions: Revisiting Lipinski's Rule of Five. Int J Pharm. 2018;549(1-2):133-149.

26. Pantsar T, Poso A. Binding affinity via docking: Fact and fiction. Molecules. 2018;23(8):1899.

27. Amin SA, Banerjee S, Ghosh K, Gayen S, Jha T. Protease targeted COVID-19 drug discovery and its challenges: Insight into viral main protease (Mpro) and papain-like protease (PLpro) inhibitors. Bioorg Med Chem. 2021;29:115860.

28. Osipiuk J, Azizi SA, Dvorkin S, Endres M, Jedrzejczak R, Jones $K A$, et al. Structure of papain-like protease from SARS-CoV-2 and its complexes with non-covalent inhibitors. Nat Commun. $2021 ; 12(1): 743$.

29. Yang CY, Phillips JG, Stuckey JA, Bai L, Sun H, Delproposto J, et al. Buried hydrogen bond interactions contribute to the high potency of complement factor D inhibitors. ACS Med Chem Lett. 2016;7(12):1092-1096.

30. Tacharina MR, Ansori ANM, Plumeriastuti H, Kusnoto, Kurnijasanti $R$, Hestianah EP. Beneficial effect of grinting grass (Cynodon dactylon) on the streptozotocin induced diabetes mellitus in the mice. Indian Vet J. 97(4):35-38

31. Yongpitakwattana $P$, Morchang A, Panya A, Sawasdee N Yenchitsomanus PT. Alpha-mangostin inhibits dengue virus production and pro-inflammatory cytokine/chemokine expression in dendritic cells. Arch Virol. 2021;166(6):1623-1632.

32. Gao LQ, Xu J, Chen SD. In silico screening of potential Chinese herbal medicine against COVID-19 by targeting SARS-CoV-2 3CLpro and angiotensin converting enzyme II using molecular docking. Chin J Integr Med. 2020;26(7):527-532

33. Zhang DH, Wu KL, Zhang $X$, Deng SQ, Peng B. In silico screening of Chinese herbal medicines with the potential to directly inhibit 2019 novel coronavirus. J Integr Med. 2020;18(2):152-158.

34. Natesh J, Mondal P, Kaur B, Abdul Salam AA, Kasilingam S, Meeran SM. Promising phytochemicals of traditional Himalayan medicinal plants against putative replication and transmission targets of SARS-CoV-2 by computational investigation. Comput Biol Med. 2021;133:104383

35. Umashankar V, Deshpande SH, Hegde HV, Singh I, Chattopadhyay D. Phytochemical Moieties from Indian traditional medicine for targeting dual hotspots on SARS-CoV-2 spike protein: An integrative in-silico approach. Front Med. 2021;8:672629. 
36. Halder P, Pal U, Paladhi P, Dutta S, Paul P, Pal S, et al. Evaluation of potency of the selected bioactive molecules from Indian medicinal plants with Mpro of SARS-CoV-2 through in silico analysis. J Ayurveda Integr Med. 2021.

37. Amparo TR, Seibert JB, Almeida TC, Costa FSF, Silveira BM, da Silva GN, et al. In silico approach of secondary metabolites from Brazilian herbal medicines to search for potential drugs against SARS-CoV-2. Phytother Res. 2021;35(8):4297-4308.

38. Rivero-Segura NA, Gomez-Verjan JC. In silico screening of natural products isolated from Mexican herbal medicines against COVID-19. Biomolecules. 2021;11(2):216.

39. Goyzueta-Mamani LD, Barazorda-Ccahuana HL, Mena-Ulecia K, Chávez-Fumagalli MA. Antiviral activity of metabolites from Peruvian plants against SARS-CoV-2: An in silico approach. Molecules. 2021;26(13):3882.

40. Umar HI, Josiah SS, Saliu TP, Jimoh TO, Ajayi A, Danjuma JB. Insilico analysis of the inhibition of the SARS-CoV-2 main protease by some active compounds from selected African plants. J Taibah Univ Med Sci. 2021;16(2):162-176.

41. Gyebi GA, Ogunro OB, Adegunloye AP, Ogunyemi OM, Afolabi SO. Potential inhibitors of coronavirus 3-chymotrypsin-like protease (3CLpro): An in silico screening of alkaloids and terpenoids from African medicinal plants. J Biomol Struct Dyn. 2021;39(9):3396-3408.

42. Fouedjou RT, Chtita S, Bakhouch M, Belaidi S, Ouassaf M, Djoumbissie LA, et al. Cameroonian medicinal plants as potential candidates of SARS-CoV-2 inhibitors. J Biomol Struct Dyn. 2021;28:1-15.

43. Aanouz I, Belhassan A, El-Khatabi K, Lakhlifi T, El-Ldrissi M, Bouachrine M. Moroccan medicinal plants as inhibitors against SARS-CoV-2 main protease: Computational investigations. J Biomol Struct Dyn. 2021;39(8):2971-2979.

44. Prasanth DSNBK, Manikanta M, Chandramohan V, Bhavya G, Lakshmana Rao A, Panda SP, et al. In-silico strategies of some selected phytoconstituents from Melissa officinalis as SARS CoV-2 main protease and spike protein (COVID-19) inhibitors. Mol Simul. 2021.
45. Murthy TPK, Joshi T, Gunnan S, Kulkarni NVP, Kumar SB, Gowrishankar BS. In silico analysis of Phyllanthus amarus phytochemicals as potent drugs against SARS-CoV-2 main protease. Current Research in Green and Sustainable Chemistry. $2021 ; 4: 100159$.

46. Kundu D, Selvaraj C, Singh SK, Dubey VK. Identification of new anti-nCoV drug chemical compounds from Indian spices exploiting SARS-CoV-2 main protease as target. J Biomol Struct Dyn. $2021 ; 39(9): 3428-3434$

47. Wijaya RM, Hafidzhah MA, Kharisma VD, Ansori ANM, Parikesit AA. COVID-19 in silico drug with Zingiber officinale natural product compound library targeting the Mpro protein. Makara J Sci. $2021 ; 25(3): 5$

48. Singh P, Chauhan SS, Pandit S, Sinha M, Gupta S, Gupta A, et al. The dual role of phytochemicals on SARS-CoV-2 inhibition by targeting host and viral proteins. J Tradit Complement Med. 2021.

49. Mouffouk C, Mouffouk S, Mouffouk S, Hambaba L, Haba H. Flavonols as potential antiviral drugs targeting SARS-CoV-2 proteases (3CLpro and PLpro), spike protein, RNA-dependent RNA polymerase (RdRp) and angiotensin-converting enzyme II receptor (ACE2). Eur J Pharmacol. 2021;891:173759.

50. Mitra D, Verma D, Mahakur B, Kamboj A, Srivastava R, Gupta S, et al. Molecular docking and simulation studies of natural compounds of Vitex negundo L. against papain-like protease (PLpro) of SARS CoV-2 (coronavirus) to conquer the pandemic situation in the world. J Biomol Struct Dyn. 2021;18:1-22.

51. Li L, Ma L, Hu Y, Li X, Yu M, Shang H, et al. Natural biflavones are potent inhibitors against SARS-CoV-2 papain-like protease. Phytochemistry. 2022;193:112984.

52. Ahmad Mir S, Firoz A, Alaidarous M, Alshehri B, Aziz Bin Dukhyil A, Banawas S, et al. Identification of SARS-CoV-2 RNA-dependent RNA polymerase inhibitors from the major phytochemicals of Nigella sativa: An in silico approach. Saudi J Biol Sci. 2021.

\section{GRAPHICAL ABSTRACT}
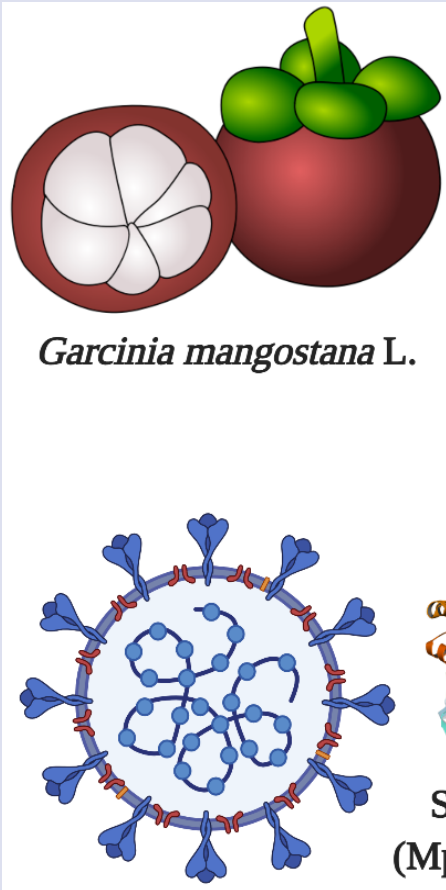

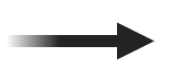

$\beta$-mangostin

Y-mangostin
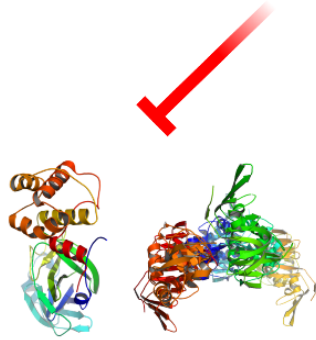

SARS-CoV-2

(Mpro and PLpro) 


\section{ABOUT AUTHORS

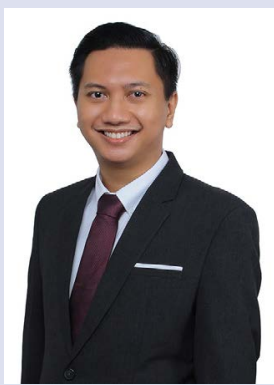 \\ Arif Nur Muhammad Ansori is a Doctoral Candidate in Veterinary Science at Universitas Airlangga, Indonesia. He completed his B.Sc. in Biology and M.Sc. in Vaccinology and Immunotherapeutics at Universitas Airlangga, Indonesia. Currently, he is an awardee of the PMDSU Scholarship (Batch III) at Universitas Airlangga, Indonesia. His research projects are related to virology, bioinformatics, and molecular biology. His actual research focus is the application of molecular biology to unlock the SARS-CoV-2 genome in Indonesia.

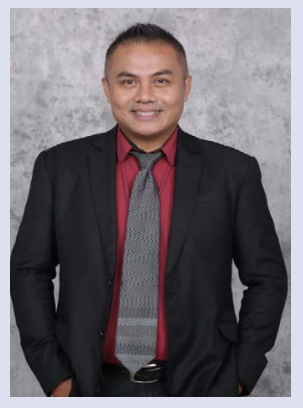 \\ Rahadian Zainul has completed a Bachelor of Educational Chemistry in IKIP Padang, then continued his studies and obtained a Master of Chemistry at Universitas Andalas and earned a Doctoral Chemistry degree at Universitas Andalas. He is a researcher on the design and modification of copper oxide for inactivation SARS-CoV-2 by stimulated indoor lights and a researcher on the design and modification of copper oxide by computation approach with DFTB+. He is also the Head of Cambiotics Research Center, Universitas Negeri Padang. The author has published 41 manuscripts in Scopus-indexed journals and also 8 h-index.}

Cite this article: Ansori ANM, Kharisma VD, Parikesit AA, Dian FA, Probojati RT, Rebezov M, et al. Bioactive Compounds from Mangosteen (Garcinia mangostana L.) as an Antiviral Agent via Dual Inhibitor Mechanism against SARS-CoV-2: An In Silico Approach. Pharmacogn J. 2022;14(1): 85-90. 